\title{
Pengembangan Sumberdaya Air Alternatif dengan Cara Transfer Sumberdaya Air dari Luar Cekungan Bandung
}

\author{
Tatas $^{1)}$, Yudi Rahayudin ${ }^{2)}$ \\ 1)Staf Pengaj ar Program Studi Diploma Teknik Sipil FTSP ITS \\ tatas@ce.its.ac.id \\ 2)Pusdiklat Geologi DESDM, Bandung \\ rahayudin@yahoo.com
}

\begin{abstract}
ABSTRAK
Krisis air bersih di Bandung di mulai sekitar tahun 1980 dan semakin pesat pada tahun 1990-an. Berbagai studi menunjukkan penurunan muka airtanah telah terjadi di beberapa titik, misalnya pada tahun 1980 di Cimahi muka airtanah 15 meter di atas tanah, pada tahun 2004 menunjukkan bahwa muka airtanah telah berada di bawah tanah hingga kedalaman 86 meter dari tanah setempat. Kejadian tersebut juga menimpa lokasi-lokasi yang lain seperti Kebon Kawung, Rancaekek, Dayeuh Kolot, dan lain-lain. Penggunaan airtanah yang berlebihan tanpa diimbangi oleh usaha konservasi menjadi salah satu penyebabnya. Berkembangnya industri dan permukiman penduduk menjadi salah satu penyebab tingginya konsumsi airtanah, sedangkan Perusahaan Daerah Air Minum Kota dan Kabupaten Bandung masing-masing baru mampu memenuhi $65 \%$ dan 13,12\% kebutuhan rumah tangga dan industri. Salah satu cara penyediaan airbaku adalah dengan cara menggunakan sistem transfer antar cekungan airtanah. Dalam penelitian ini dicoba dikaji potensi cekungan airtanah yang berada di sekitar Cekungan Airtanah Bandung. Metodologi yang digunakan adalah dengan mengkaji penelitian-penelitian sebelumnya, interview dengan pihak terkait, dan dilakukan analisis ekonomi untuk selanjutnya diambil kesimpulan. Berdasarkan hasil analisis dapat diambil kesimpulan bahwa dari segi jarak CAT Ciater merupakan yang terdekat dengan pusat Kota Bandung yaitu $23,8 \mathrm{~km}$. Namun demikian dari segi ekonomis transfer air antar akifer menggunakan truk air belum dapat sistem.
\end{abstract}

Kata Kunci:

\section{PENDAHULUAN}

Salah satu cara penyediaan air baku dapat dilakukan dengan cara mengunakan sistem transfer airtanah antara cekungan airtanah yang berbeda. Untuk sistem transfer ini, seringkali melibatkan dua sistem administrasi, seperti antar negara (Singapura-Malaysia; Hongkong-China), antar propinsi (DKI Jakarta - Jawa Barat), antar kabupaten/ kota (Sidoarjo-Pasuruan; Kuningan-Cirebon).

Perlu adanya transfer air antar cekungan ini karena :

1. keterbatasan jumlah dan akses sumber air baku,
2. keterbatasan sumber air bersih,

3. sumber air yang tidak layak konsumsi pada wilayah tertentu.

4. faktor lingkungan : penurunan muka airtanah yang berlebihan sehingga menyebabkan land-subsidence maupun intrusi air laut.

Saat ini, Kota dan Kabupaten Bandung (Cekungan Airtanah Bandung) telah mengalami masalah-masalah tersebut. Perusahaan Daerah Air Minum (PDAM) sebagai penyedia air baku penduduk saat ini belum mampu memenuhi secara penuh kebutuhan penduduk akan air baku. PDAM Kota Bandung baru mampu menyediakan air baku untuk 65\% kebutuhan Kota Bandung, sedangkan PDAM Kabupaten Bandung baru 
mampu menyediakan 13,12\% kebutuhan total Kabupaten Bandung. Cekungan Airtanah Bandung telah mengalami beberapa kondisi tersebut.

Seperti yang telah diuraikan di bagian atas, PDAM Kota Bandung baru mampu mensuplai $65 \%$ kebutuhan masyarakat Bandung, sedangkan untuk PDAM Kabupaten Bandung baru melayani $13,12 \%$ kebutuhan masyarakat, keterbatasan jumlah dan akses karena jaringan pipa air PDAM yang jauh dari masyarakat merupakan fakta yang ada selama ini.

Untuk kondisi kedua, fakta yang ada di lapangan adalah dengan matinya beberapa mata air di Cekungan Bandung. Awalnya muka airtanah bisa mencapai di atas permukaan tanah, namun hampir 25 tahun berikutnya muka airtanah telah turun hingga puluhan meter di bawah muka tanah (lihat Tabel 1). Matinya mata air tersebut mengindikasikan bahwa recharge untuk mata air di daerah tersebut berkurang atau bahkan sudah tidak ada imbuhan Iagi. Selain itu turunnya muka airtanah juga bisa menjadi sebab berkurangnya sumber air bersih.

Tabel 1. Perbandingan Muka Airtanah Tahun 1980 dan 2004 beberapa Lokasi di Cekungan Bandung

\begin{tabular}{|l|l|l|}
\hline Lokasi & 1980 & 2004 \\
\hline Cimahi & $+15 \mathrm{~m}$ & $-86 \mathrm{~m}$ \\
\hline Kebon Kawung & $+22 \mathrm{~m}$ & $-36 \mathrm{~m}$ \\
\hline Rancaekek & $+1 \mathrm{~m}$ & $-39 \mathrm{~m}$ \\
\hline Lanud Sulaeman & $+7 \mathrm{~m}$ & $-14 \mathrm{~m}$ \\
\hline Dayeuh Kolot & $+2 \mathrm{~m}$ & $-55 \mathrm{~m}$ \\
\hline Banjaran & $+2 \mathrm{~m}$ & $-20 \mathrm{~m}$ \\
\hline Majalaya & $+3 \mathrm{~m}$ & $-41 \mathrm{~m}$ \\
\hline
\end{tabular}

Sumber: Wirakusumah, 2006, dalam Abidin dkk, 2006. [1]

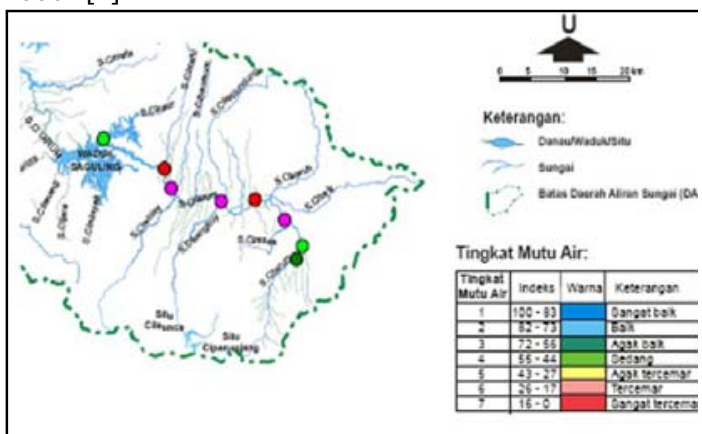

Gambar 1. Tingkat mutu air di beberapa titik sungai di Cekungan Bandung [2].
Kondisi terakhir alasan dilakukannya transfer antar cekungan adalah bila eksploitasi airtanah di suatu wilayah telah menyebabkan terjadinya penurunan permukaan tanah (land-subsidence). Peneliti-peneliti terdahulu telah menyimpulkan bahwa telah terjadi penurunan muka airtanah sehingga mengakibatkan penurunan permukaan tanah juga di Cekungan Bandung. Dalam Anonym [3], rata-rata penurunan permukaan tanah di Cekungan Bandung berkisar antara $1 \mathrm{~cm}$ (di Rancaekek periode J uli 2002 - J uni 2003) hingga mencapai $19 \mathrm{~cm}$ terjadi di Cimahi, periode Pebruari 2000 - Nopember 2001. Data penurunan permukaan tanah dapat dilihat di Gambar 2 berikut ini.

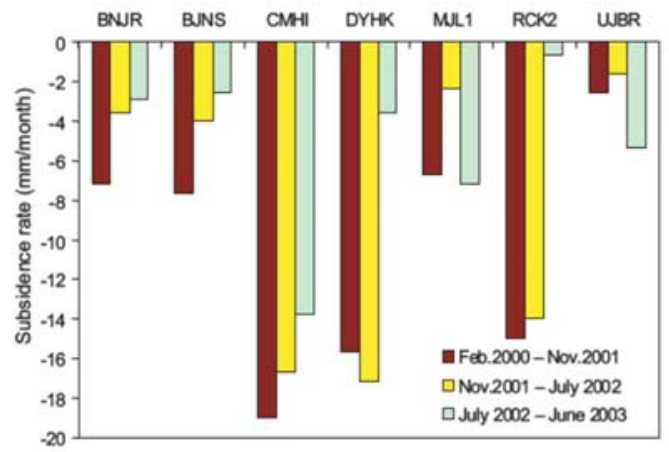

Catatan : BNJ R, BJ NS, CHMI, DYHK, MJ 1, RCK2, UJ BR berturut-turut adalah Banjaran, Bojong Soang, Cimahi, Dayeuhkolot, Majalaya 1, Rancaekek 2, Ujungberung.

\section{Gambar 2. Rata-rata penurunan permukaan tanah di beberapa titik di Cekungan Bandung [1].}

\section{POTENSI AIRTANAH SEKITAR CAT BANDUNG}

Dalam rangka pengembangan alternatif sumber daya air, perlu dilakukan eksplorasi di luar kawasan yang bersangkutan, dalam hal ini kawasan Cekungan Airtanah Bandung. Berdasarkan Atlas Cekungan Airtanah Indonesia yang dikeluarkan Badan Geologi DESDM, ada 6 cekungan airtanah yang berbatasan langsung dengan Cekungan Airtanah Bandung. Cekungan airtanah tersebut adalah Ciater, Sumedang, Malangbong, Garut, Banjarsari, dan Cibuni (lihat Gambar 3). 


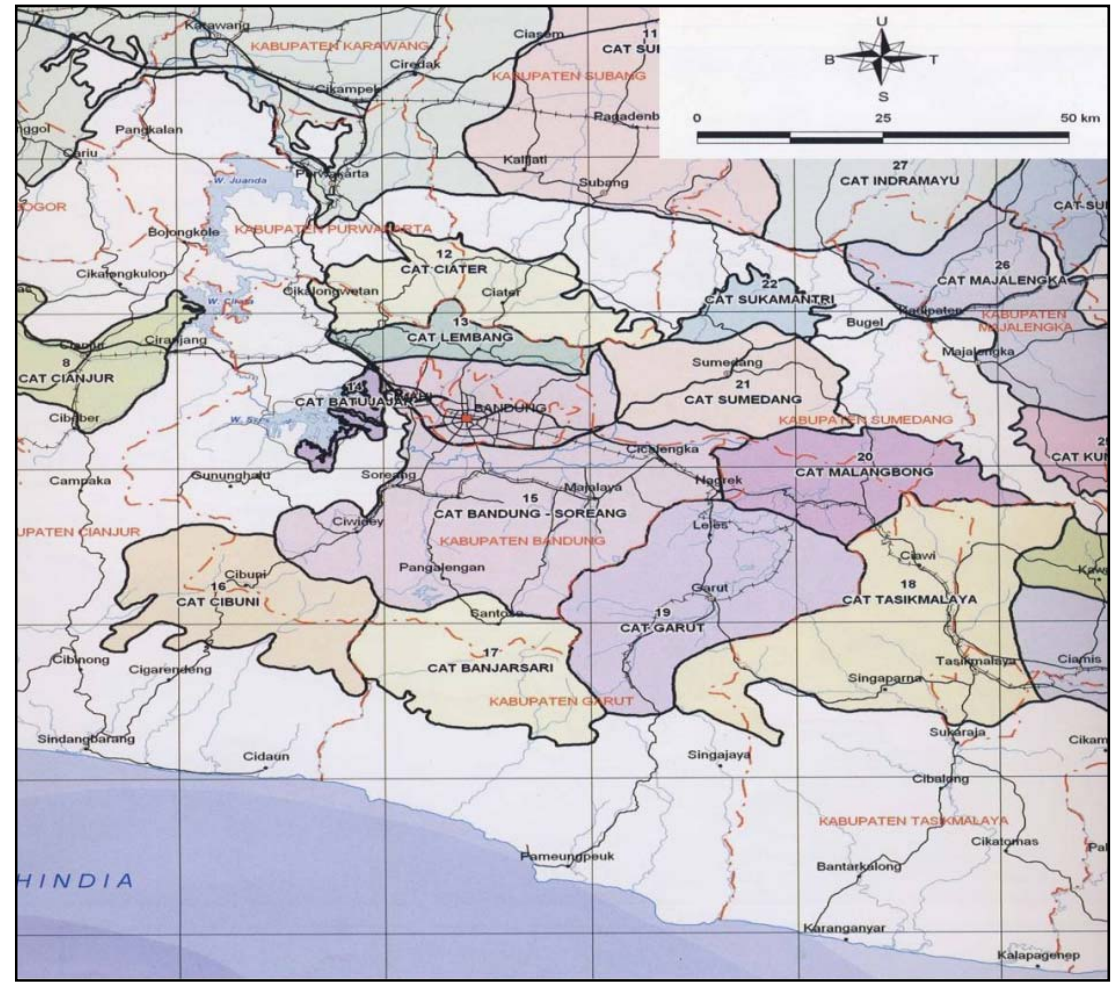

Gambar 3. Cekungan Airtanah Bandung (CAT Bandung-Soreang, CAT Batuj ajar, CAT, Lembang) dan sekitarnya (sumber : Sukrisna [5]).

Menurut Danaryanto [4], potensi airtanah di CAT Bandung adalah 1025 juta $\mathrm{m}^{3} /$ th di akifer bebas dan 134 juta $\mathrm{m}^{3} /$ th di akifer tertekan. Adapun besar potensi airtanah untuk akifer bebas dan tertekan di cekungan airtanah sekitar CAT Bandung berturut-turut adalah CAT Ciater 413 juta $\mathrm{m}^{3} /$ th dan 30 juta $\mathrm{m}^{3} / \mathrm{th}$, CAT Sumedang 519 juta $\mathrm{m}^{3} /$ th dan 28 juta $\mathrm{m}^{3} / \mathrm{th}$, CAT Malangbong 415 juta $\mathrm{m}^{3} /$ th dan 30 juta $\mathrm{m}^{3} /$ th, CAT Garut 691 juta $\mathrm{m}^{3} /$ th dan 87 juta $\mathrm{m}^{3} /$ th, CAT Cibuni 595 juta $\mathrm{m}^{3} /$ th dan 28 juta $\mathrm{m}^{3} /$ th (lihat Tabel 2).

Pengembangan alternatif penyediaan air melalui sistem transfer antar cekungan, harus mempertimbangkan jarak antara cekungan donor dan cekungan penerima. Untuk itu perlu dilakukan perhitungan jarak antar cekungan donor (cekungan airtanah di luar CAT Bandung) dan CAT Bandung (cekungan penerima). jarak yang dimaksud bisa berupa jarak terdekat tanpa mempertimbakan kondisi morfologi maupun topografi, maupun jarak yang mempertimbangkan kedua aspek tersebut.
Berdasarkan Gambar 3, dilakukan estimasi jarak antara cekungan airtanah di sekitar CAT Bandung ke Kota Bandung, sehingga diperoleh jarak rata-rata antara cekungan donor dengan cekungan penerima. Estimasi jarak adalah berdasarkan jalan transportasi yang menghubungkan kedua wilayah cekungan airtanah.

Tabel 2. Luas, potensi airtanah, dan jaraknya ke Kota Bandung

\begin{tabular}{|l|r|r|r|r|}
\multicolumn{1}{c|}{ CAT } & \multicolumn{1}{|l}{ Luas } & $\begin{array}{l}\text { Akifer } \\
\text { Bebas } \\
\text { juta } \\
\mathrm{m}^{3} / \text { th }\end{array}$ & $\begin{array}{l}\text { Akifer } \\
\text { Terteka } \\
\mathrm{n} \text { juta } \\
\mathrm{m}^{3} / \mathrm{th}\end{array}$ & $\begin{array}{l}\text { Jarak ke } \\
\text { Kota } \\
\text { Bandung } \\
\mathrm{km}\end{array}$ \\
\hline Bandung & 1974 & 1025 & 134 & - \\
\hline Ciater & 566 & 413 & 30 & 23,8 \\
\hline Sumedang & 483 & 519 & 28 & 43,4 \\
\hline Malangbong & 514 & 415 & 30 & 60,7 \\
\hline Garut & 886 & 691 & 87 & 58,2 \\
\hline Banjarsari & 605 & 550 & 30 & 45,9 \\
\hline Cibuni & 621 & 595 & 28 & 44,3 \\
\hline
\end{tabular}

Sumber : Danaryanto, dkk. [4]; estimasi jarak oleh penulis. 
Tabel 2 memperlihatkan bahwa di antara cekungan airtanah di sekitar CAT Bandung Cekungan Airtanah Ciater merupakan daerah dengan jarak jalan transportasi paling dekat, yaitu sekitar 23,8 km, sedangkan yang terjauh adalah CAT Malangbong dengan jarak $60,7 \mathrm{~km}$, disusul CAT Garut dengan jarak 58, 2 km. Sedangkan cekungan airtanah yang lainnya berkisaran pada jarak $40 \mathrm{~km}$ an. Berdasarkan hitungan jarak tersebut CAT Ciater memiliki jarak terpendek yang ekstrim jika dibandingkan cekungan airtanah yang lainnya. Sehingga jika hanya mempertimbangkan jarak jalan transportasi terdekat, maka CAT Ciater paling rasional untuk dipilih sebagai cekungan donor untuk Cekungan Bandung.

\section{SISTEM TRANSFER}

Sistem transfer air antar cekungan secara umum, pada dasarnya dapat dilakukan dengan berbagai macam cara, yaitu: menggunakan jaringan pipa, saluran terbuka, atau menggunakan moda transportasi (truk tangki air). Penggunaan jaringan pipa, seperti yang dilaksanakan di Malaysia-Singapura, biasanya digunakan untuk transfer air bersih. Metode ini digunakan untuk mempertahankan kualitas air yang dialirkan. Sistem saluran terbuka (trench) biasanya digunakan untuk mentransfer air irigasi, contoh metode ini ada di Amerika Serikat, yang tidak mempertimbangkan kebersihan atau kualitas air. Dan yang terakhir, penggunaan truk tangki air, metode ini banyak dilakukan di Indonesia maupun negara berkembang lainnya, terutama untuk daerah dengan akses air bersih yang kurang. Seperti yang dilakukan di Sidoarjo (masuk dalam CAT Surabaya-Lamongan), karena kualitas airtanah yang asin (daerah pantai) dan jaringan pipa PDAM yang tidak ada, maka masyarakat menggunakan jasa truk tangki air untuk transfer air baku (airtanah) yang diambil dari Cekungan Airtanah Pasuruan.

Ketiga cara tersebut, pemilihannya bergantung pada beberapa aspek seperti kualitas air, topografi, aksesbilitas dari cekungan donor ke cekungan penerima. Dari segi kualitas air, pemilihan jenis sistem transfer telah dijelaskan di paragraf sebelumnya. Berdasarkan alasan topografi, jika cekungan donor berada pada elevasi yang lebih tinggi, maka penggunaan sistem transfer dengan jaringan pipa atau saluran terbuka dapat dilakukan dengan aliran gravitasi. Namun jika cekungan donor berada pada elevasi lebih rendah sistem transfer tersebut bisa juga digunakan, namun dengan bantuan pompa air. Penggunaan truk tangki air lebih fleksibel, asalkan akses jalan darat antar cekungan donor dan penerima sudah ada.

\section{ANALISIS SISTEM TRANSFER}

Dari beberapa uraian-uraian sebelumnya, maka yang menjadi pertanyaan adalah murahkah sistem transfer airtanah antar cekungan ini jika dipilih sebagai alternatif untuk memenuhi kebutuhan air dan untuk meredam eksploitasi airtanah di Cekungan Airtanah Bandung.

Untuk sumber air di Ujungberung saja, penjualan air dalam satu tangki (5.000 liter) di tingkat konsumen di Bandung berkisar pada angka Rp 110.000,00 (harga beli di lokasi Rp 15.000,00), artinya untuk per meter kubik air, konsumen harus mengeluarkan uang sebesar Rp 22.000,00.

Harga tersebut jauh lebih mahal dari pada jika masyarakat menggunakan air PDAM, yang untuk skala rumah tangga cukup membayar Rp 2.000,00 hingga Rp 5.000,00 per meter kubiknya.

\section{PERTIMBANGAN SISTEM TRANSFER ANTAR CEKUNGAN AIRTANAH}

Harga tersebut masih sangat mahal untuk konsumen, padahal sumber lokasi pengambilan masih berada di wilayah Bandung, jika mengambil airtanah dari luar Cekungan Airtanah Bandung, tentunya harganya jauh lebih mahal, karena jarak yang lebih jauh. Aspek jarak tersebut, tentunya sangat mempengaruhi nilai investasi dan harga jual untuk tingkat konsumen. Sehingga pada tahap ini masih sangat mahal sistem transfer antar cekungan untuk mengatasi masalah airtanah di Cekungan Airtanah Bandung.

Selain aspek jarak, sebagai pertimbangan untuk melakukan sistem transfer airtanah 
antar cekungan airtanah, maka aspek ketahanan airtanah di cekungan donor melalui kajian hidrogeologi sangat diperlukan. Hal tersebut perlu dilakukan agar permasalahan krisis airtanah di CAT Bandung (dengan indikasi turunnya muka airtanah dan adanya land-subsidence) tidak terjadi juga di cekungan donor, seehingga tidak terkesan memindahkan permasalahan.

Pertimbangan yang ketiga adalah harga jual ditingkat konsumen. Hal ini juga terkait dengan faktor jarak. Jika harga jual ditingkat konsumen sangat mahal, tentunya kurang direkomendasikan untuk dilakukan sistem transfer antar cekungan.

Sistem transfer antar cekungan merupakan pertimbangan selanj utnya. Pemilihan sistem transfer ini tentunya terkait dengan nilai investasinya, apakah lebih ekonomis menggunakan jaringan pipa, saluran terbuka, atau menggunakan alat transportasi.

Dan pertimbangan yang terakhir adalah legal aspek yang terkait dengan airtanah maupun kerjasama antar wilayah administrasi jika baik cekungan donor maupun penerima ada di dua wilayah administrasi yang berbeda.

\section{KESIMPULAN}

Pengembangan alternatif pemenuhan kebutuhan air dengan sistem transfer airtanah antar cekungan di Cekungan Bandung belum direkomendasikan untuk saat ini, jika harga ekonomisnya masih menggunakan acuan harga saat ini. Sehingga perlu dipikirkan model lain untuk sistem transfernya, misalnya dengan menggunakan pipa air.

\section{DAFTAR PUSTAKA}

[1] Abidin, Hasanuddin Z., dkk, 2006, Land Subsidence Characteristics of Bandung Basin between 2000 and 2005 as Estimated from GPS Surveys, TS 29 Landslide Control and Monitoring Surveys, Shaping the Change XXIII FIG Congress, Munich.

[2] Anonim, --, Status Mutu Air Sungai : Studi Kasus Sungai Citarum, Puslitbang SDA, Bandung

[3] Anonim, --, Alternative Water Resources and Recycle Program as Effort to Strengthen Ground Water Management in Metropolitan Bandung, Sustainable Groundwater Management in Asian Cities, --,---.

[4] Danaryanto, dkk, 2005, Air Tanah di Indonesia dan Pengelolaannya, Direktorat Tata Lingkungan Geologi dan Kawasan Pertambangan, J akarta.

[5] Sukrisna, dkk, 2007, Atlas Cekungan Air Tanah Indonesia : Lembar Provinsi J awa Barat dan DKI Jakarta, Pusat Lingkungan Geologi, Bandung. 